\title{
HUMANIST ISLAM IN INDONESIA AHMAD SYAFII MAARIF PERSPECTIVE
} Muthoifin $^{1 *}$, Sudarno Shobron ${ }^{2}$, Suhaimi Ab Rahman ${ }^{3}$

${ }^{1 *}$ Post Graduate Program of Islamic Law, Universitas Muhammadiyah Surakarta, Surakarta 57102, Indonesia, ${ }^{2}$ Post Graduate Program of Islamic Education, Universitas Muhammadiyah Surakarta, Surakarta 57102, Indonesia, ${ }^{3}$ Faculty of Economics and Management, Universiti Putra Malaysia, Selangor Darul Ehsan, Malaysia.

Email: ${ }^{1 *}$ mut122@ums.ac.id, ${ }^{2}$ ss172@ums.ac.id, ${ }^{3}$ suhaimiabrahman@upm.edu.my

Article History: Received on $12^{\text {th }}$ October 2019, Revised on $29^{\text {th }}$ November 2019, Published on $19^{\text {th }}$ December 2019

\section{Abstract}

Purpose of the Study: The issue focused on this study is how is the idea of the Islamic conception in the concept of humanity and Indonesianness? Whereas the purpose of this study is to reveal the perspective of Ahmad Syafii Maarif on Islam Indonesia and the concept of humanism.

Methodology: The method used is qualitative, with a historical, phenomenological, biographical, sociological, and normative approach.

Results: The result from this study concluded that this is no longer the time for Muslims, who are the majority in this archipelago, to question the trilogy correlation between Islam, Indonesianness, and humanity. The three conceptions must be in the same breath and rhythm so that Islam that is thriving in Indonesia is Islam that is progressive, hospitable, open and rahmatanlil 'alamin.

Applications: This research can be used for universities, teachers, and students.

Novelty/Originality: The study focused more on the description of the thinking of a figure or a person and emphasized on the process with deductive, inductive, interpretative, and comparative methods, especially on the thinking of Ahmad Syafii Maarif about the concept of Islam in the frame of Indonesianness.

Keywords: Islam Nusantara, Progressive Islam, Indonesianness, Humanity, Humanist.

\section{INTRODUCTION}

Discussing the issue of Islam and humanity particularly in Indonesia and Islam of the world in general, it is, of course, inseparable from the national figure and Islamic thinker named Ahmad Syafii Maarif. This is because various strategic concepts of Islam, Indonesianness, and humanity have been thought about and formulated long ago by a figure widely known as a Muslim scholar and teacher of the people. His concept and thinking reflexions arise from concern over the condition that Muslims, who are the majority population in this archipelago, are still questioning the trilogy correlation between Islam, Indonesianness, and humanity. According to him, the three conceptions must go hand in hand so that Islam that is thriving in Indonesia is Islam that is hospitable and open. (Maarif, 2018; Biyanto, 2009)

This is the challenge and also opportunity that will be worked on and campaigned by Ahmad Syafii Maarif. According to him, if Islam, Indonesianness, and humanity already go hand in hand in the mind, soul, and action of Muslims in Indonesia, then Islam Indonesia will be able to provide a solution towards major issues faced by the country. A form of Islam that is dynamic and friendly, that delivers justice, safety, and protection to the entire population of the archipelago. A form of Islam that entirely stands by the poor people and rejects poverty so that it will be successfully driven away from the Unitary State of the Republic of Indonesia. (Matin, 2019)

Islam was born and grew within the blood and flesh, not into the desolation of culture. So that within the context of religionhistory, Islam has, is, and will always struggle with an environment that is always changing. Because the purpose of Islam is to direct the path of change so that it will not slip from the path of the prophet and from the way of justice. Nevertheless, often time Islam is being exiled from coming in contact with the culture and social facts. This is what results in Islam being ahistorical and indecisive when faced with change and failed to carry out its mission of guiding civilization. (Fancy, 2007; Dogan, 2018)

In line with the reasoning of Ahmad Syafii Maarif, another Islamic thinker Said Aqil Siraj also strongly believes that at this moment, Islam has become an important topic of studies, research, and also discourse that interests the general public. This is because the archipelago area has become more strategic in the regulation of international geopolitics. The studies of Islam and Indonesia have begun to be held intensively. This is the reason why the government of the Indonesian Republic driven by the Ministry of Religion and Islamic community organizations along with their elements often held studies focusing on themes relating to Islam and the archipelago or Islam and Indonesianness in the middle of this dynamics. (Asroni, 2011) 
This measure is considered very important in order to understand Indonesia, especially the religion of Islam in the archipelago, namely Islam that was born and struggle and also is rooted in the Indonesian culture from the perspective of the archipelago-Indonesia. Not from the perspective of the West or Arab, which has always been biased in understanding humanity and Indonesianness? (Maarif, 2018)

Nurmila (2013) also admitted that she is very interested in studying Islam from an Indonesian Muslim lecturer. According to her, all this time the study of Islam is more focused on the Middle East, even though Indonesia has the largest Muslim population. Other than that, they are also starting to get tired of studying Islam focusing on the Middle East which tends to be full of conflicts. Hence, they wanted to understand the Islamic perspective from a country like Indonesia, where the majority of the population is Muslims and can live peacefully with various other religions. (Sholikin, 2013)

Therefore, it must be recognized that in the course of Islam and Indonesianness, it has become a new trend and concept in various regions in Indonesia as well as the Muslim communities around the world. This trend has the opportunity to make the President of the Indonesian Republic, Joko Widodo, welcome the concept and affirmation of Islam of the Archipelago (Islam Nusantara), which is Islam Indonesia that is polite, friendly, tolerant, moderate, fair, civilized, and also respects humanity. (Maarif, 2018) After reviewing comments and concepts of Islam and Indonesianness from various figures and observers of Islam Indonesia, it is decided that the focus of the discussion in this study is raising the theme of how is the thinking of Ahmad Syafii Maarif on Islam in the frame of humanity and Indonesianness?

Who is the Muslim scholar Ahmad Syafii Maarif? The man generally called Maarif was born in Sumpur Kudus, West Sumatra, on May $31^{\text {st, }} 1935$. Previously a lecturer at FPIPS IKIP, IAIN Sunan Kalijaga and Islamic University of Indonesia (UII) Yogyakarta. Advisor for PP Muhammadiyah (2005-now), and Founder of Maarif Institute (2002-now).Previously studied at Madrasah Mualimin Muhammadiyah Lintau (1953) and Yogyakarta (1956), FKIP Cokroaminoto University of Surakarta until baccalaureate degree (1964). Graduated from FKIS IKIP Yogyakarta (1968), studied History at Northern Illinois University (1973), and received an M.A degree in History at Ohio University, Athens, United States (1980). Earned a Ph.D. degree in the field of Islamic intellection at the University of Chicago, Chicago, United States (1983, with the dissertation titled "Islam as the Basis of State: A Study of the Islamic Political Ideas as Reflected in the Constituent Assembly Debates in Indonesia." While being a lecturer as well as studying in the United States, very often attended seminars and symposiums both inside and outside of the country, and also writes for journals. (Biyanto, 2009; Maarif, 2018.)

Until today, he is still very active as a columnist and speaker both inside and outside of the country. Furthermore, the awards that has been obtained are: Hamengku Buwono IX (2004) on his persistence in fighting for a harmonious life of building a good relationship between religions, Magsaysay Award in 2008 (Manila, August 31 ${ }^{\text {st }}$ 2008) for the Peace and International Understanding category, Bacharuddin Jusuf Habibie Award in 2010 in the special field of Harmony in Religious Life, Islamic Book Figure in 2011 (March $4^{\text {th, }}$ 2011) from the Islamic Book Fair (IBF) Award for his work that is considered to provide inspiration and contribution for the advancement of books, especially Islamic books, in Indonesia. (Damanhuri, $\underline{2015)}$

Received the Indonesian Community of Public Administration (MIPI) Award in 2011 (May 28 ${ }^{\text {th, }}$ 2011) for the category of Government Observer Figure for his never-ending work to delivering constructive criticism, and the latest is the Lifetime Achievement Soegeng Sarjadi Award on Good Governance for the category of Intellectual Integrity from Soegeng Sarjadi Syndicate (August $18^{\text {th }}$ 2011) that considers Buya as a figure who continuously fight for public rights through criticism and appeals for the enforcement of justice in Indonesia. (Maarif, 2018)

\section{LITERATURE REVIEW}

To this date, there are many concepts about Islam and Indonesia that are not accurate and not contextual with today's condition and spirit, even though humans live and have awareness consistent with the condition and mindset of their time. This is the reason why the interpretation of Islam that is in accordance with the era is needed in order for Islam to not be foreign for its own followers. On the other hand, it will be more relevant and become something people can hold on to in the middle of the wave of modern life. (Nashir, Jinan, \& Setiaji, 2019)

Moreover, today the Muslims in Indonesia has entered the present era, which is the era of regional autonomy with very strategic roles. Because various fields and sectors in the government are under its control, but if the act of handling and implementing is not accurate, then what happens is that the Muslims in Indonesia will fail and be left behind in various fields, including social, religion, politic, culture, and economy. It is true that in this era of decentralization, Muslims in Indonesia are still faced with various strategic issues, starting from issues of terrorism and disharmony to issues surrounding the natural and human resources management that are not optimal. There are also issues of economic disparity, issues of poverty, unbalanced construction of infrastructures, the dreary portrait of the educational system, criminalization of policies, conflicts between religion and ethnic groups, terrorism, LGBT (Lesbian Gay Bisekual Transgender) fake vaccines, to corruption issues of local officials. (Zuhdi et al., 2019) 
Nurcholis Madjid in his book titledNational Development, The Dilemma between Growth and Social Justice stated: Attempts made to stimulates the economy in regionals in order to create the welfare and prosperity of the nation is needed urgently if we don't want to be left behind by our neighboring countries with all of the consequences. However, ambitions to actualize the welfare and social justice for all people have become national principle awareness and attached to the ambitions of the country. This is what brings us to the dilemmatic situation, between imperative economic growth and moral obligation to create social justice. (Muthoifin \& Nuha, 2016)

\section{Indonesia and the Dynamics}

Indonesia is a multicultural and compound nation with both burden and potentials. On one hand, pluralism is a national value with great potentials in the attempt to reach the nation's ambition as a large and strong country. But, on the other hand, the pluralism and differences can become a disintegrative factor for the wholeness of the nation, even making Indonesia an easy target of conflicts and discrimination. (Tyson, 2003)

Indonesia used to be very susceptible to conflicts. In fact, conflicts have broken out almost in every region. Like Denny J.A wrote in his book, Indonesia Without Discrimination, there have been at least five cases of the worst conflicts in this archipelago. A variety of cases and modus have arise, like the conflict between Muslims and Christians in Maluku, ethnical conflict between Dayak and Madura in Sampit, Central Kalimantan and Sambas, West Kalimantan, ethnical violence towards Tionghoa in Jakarta, massacre of the Ahmadiyah community in Mataram who has become refugee since 2005, and massacre of the Hindus in Lampung. (Septiaji, 2018)

The same as the conflict between Sunni followers with Syiah followers in various areas, like the case of the burning and scorching of the Syiah's religion school and the house of worship in Sampang Madura. The attack of Ustadz Arifin Ilham's Az-Zikra religion school by a group of Syiah followers in Bogor. And also the attack of jama'ah Ahmadiyah in the Banten Province that was claimed to teach misguided teachings of religion, resulting in the loss of a few lives.(Septiaji, 2018)

According to Denny J.A, these conflicts happen because these groups only think about their own group's egoism; put forward their ethnical fanatism; accentuating their own interests; even claiming their own religious teachings to be the right one. If this happens and nothing is done to prevent it, then what took place will be the law of the jungle, where the strong slaughtered the weak, the big pushed the small, the majority oppressed the minority, the natives drove away from the newcomers and other deviations. (Pager \& Western, 2012)

\section{METHODOLOGY}

This study is categorized as qualitative research. It is considered qualitative, because the study focused more on the description of the thinking of a figure or a person and emphasized on the process with deductive, inductive, interpretative, and comparative methods, especially on the thinking of Ahmad Syafii Maarif about the concept of Islam in the frame of Indonesianness. Because the focus is descriptive, the study is also natural and inductive. As stated by Bodgan and Biklen, qualitative research has five special characteristics, that is: (a) naturalistic, (b) descriptive, (c) focus on the process, (d) inductive, and (e) focus on the meaning. (Gunawan, 2013)

The approach used is the historical approach. Historical or history is a science or knowledge discussing and examining many events with regard to the elements of location, time, object, background, and subject of the particular event. According to Mujahidin, the research of history is a method used as guidelines in carrying out a study of historical events and its issues. In other words, the historical research method is an instrument to reconstruct historical events (history as past actuality) to history as a story or history as written. (Williams, 2007)

\section{RESULTS AND DISCUSSION}

Ahmad Syafii Maarif believed that the relationship between Indonesia, Indonesianness, and humanity is an inseparable cultural relationship. Furthermore, this relationship must be put into one single line. Islam was born and grew within the blood and flesh, not into the desolation of culture. So that within the context of religion-history, Islam has, is, and will always struggle with an environment that is always changing. Because the purpose of Islam is to direct the path of change so that it will not slip from the path of the prophet and from the way of justice. Islam is not hard-hearted and rude, radical and full of terror. (Pager \& Western, 2012)

On the considerations of Islam and Indonesia, Ahmad Hasyim Muzadi expressed his disapproval of the term Islam of the archipelago (Islam Nusantara). Hasyim prefers the term of Islam rahmatan lilalaminn (rahmat for all beings) According to him, Islam rahmatan lilalamin is more authentic because it is written in al-Qur'an, so it cannot be wrong. Hasyim Muzadi was even asked to accompany the PM of Malaysia at the time, Abdullah Badawi, to join and support the Islam Hadlori (progressive Islam), but he did not respond, because to him, Islam has a more accurate term and not limited by time, place and location. (Muhammad, Rijal \& Yumitro, 2018) 
At this moment, Islam has become an important topic of studies, research, and also discourse that interests the general public. This is because the archipelago area has become more strategic in the regulation of international geopolitics. The studies of Islam and Indonesia have begun to be held intensively. This is the reason why the government of the Indonesian Republic driven by the Ministry of Religion and Islamic community organizations such as PBNU (Chief of the Nahdlatul Ulama Executive Board) and Muhammadiyah, along with their elements often held studies focusing on themes relating to Islam and the archipelago or Islam and Indonesianness in the middle of this dynamics. (Biyanto, 2009)

This measure is considered very important in order to understand Indonesia, especially the religion of Islam in the archipelago, namely Islam that was born and struggle and also is rooted in the Indonesian culture from the perspective of the archipelago-Indonesia. Not from the perspective of the West or Arab, this has always been biased in understanding Islam of the archipelago. (Suprapto, 2017)

Ahmad Syafii Maarif believed that the relationship between Indonesia, Indonesianness, and humanity is an inseparable cultural relationship. Furthermore, this relationship must be put into one single line. Islam was born and grew within the blood and flesh, not into the desolation of culture. So that within the context of religion-history, Islam has, is, and will always struggle with an environment that is always changing. Because the purpose of Islam is to direct the path of change so that it will not slip from the path of the prophet and from the way of justice. Islam is not hard-hearted and rude, radical and full of terror. Even though lately, there have been many wrong stigmas about Islam. (Hartono, Haryanto, \& Asrowi, 2018)

\section{Indonesian Archipelago as the Third Example of Islamic Studies}

An observer from Fullbright Visiting Professor at the University of Redhlands, United States, is very interested to study Islam from Indonesian Muslim lecturers. Her reason is that all this time, the study of Islam focused more on the Middle East, although Indonesia has the largest Muslim population in the world. Other than that, they are also starting to get tired of studying Islam focusing on the Middle East which tends to be full of conflicts. Hence, they wanted to understand the Islamic perspective from a country like Indonesia, where the majority of the population is Muslims and can live peacefully with various other religions. (Nurmila, 2014)

In other words, Indonesia owns a unique version of Islam: moderate, pluralism, and full of peace. This uniqueness is needed by the people of the world that wanted to balance the media's negative image of Islam. As collected by Horgan, that since the September 11 tragedy on the WTC in the United States, many countries in the world started to search for formats in order to manage and control radicalism in any form. (Askuri \& Kuipers, 2019)

The ideas and thoughts are listed in Table 1 among the Muslim leaders in Indonesia. These were divided into three: Progressive Islam, Nusantara Islam, and Humanist Islam.

Table 1: Ideas of Developing Humanist Islam and the Nusantara: Perspective of Muslim Leaders in Indonesia

\begin{tabular}{|c|c|c|c|c|}
\hline No & $\begin{array}{l}\text { Islamic } \\
\text { Model }\end{array}$ & Figure & Position / Position & Ideas and Thought \\
\hline \multirow[t]{3}{*}{1} & Progressive & Prof. $\quad$ Dr. & Former Chairman of & Washatiyah Islam, moderate, tolerant \\
\hline & Islam & Syamsuddin. & $\begin{array}{l}\text { Muhammadiyah Central } \\
\text { Leadership. 2005-2015 }\end{array}$ & \\
\hline & & $\begin{array}{lll}\text { Prof. } & \text { Dr. } & \text { Haidar } \\
\text { Natsir. } & & \\
\end{array}$ & $\begin{array}{l}\text { Muhammadiyah Central } \\
\text { Management. 2015-2020 }\end{array}$ & $\begin{array}{l}\text { A progressing Islam, renewal and } \\
\text { enlighten all components. }\end{array}$ \\
\hline \multirow[t]{2}{*}{2} & $\begin{array}{l}\text { Nusantara } \\
\text { Islam }\end{array}$ & $\begin{array}{l}\text { Dr. A. Hasyim } \\
\text { Muzadi. }\end{array}$ & $\begin{array}{l}\text { Former Chairman of the } \\
\text { Nahdlatul Ulama Board of } \\
\text { Directors'. 2005-2015 }\end{array}$ & $\begin{array}{l}\text { Islam is able to bring the grace of the } \\
\text { universe and for the benefit of the } \\
\text { people. }\end{array}$ \\
\hline & & $\begin{array}{l}\text { Prof. Dr. Said Aqil } \\
\text { Siraj. }\end{array}$ & $\begin{array}{l}\text { Chief of the Nahdlatul } \\
\text { Ulama Executive Board. } \\
\text { 2015-2020. }\end{array}$ & $\begin{array}{l}\text { The style of Islam can not be separated } \\
\text { from the local traditions of the } \\
\text { archipelago. }\end{array}$ \\
\hline \multirow[t]{2}{*}{3} & $\begin{array}{l}\text { Humanist } \\
\text { Islam }\end{array}$ & $\begin{array}{l}\text { Abdurragman Wahid } \\
\text { (Gus Dur). }\end{array}$ & Indonesian President to 4. & $\begin{array}{l}\text { Harmony in diversity, pluralism, } \\
\text { inclusivism. }\end{array}$ \\
\hline & & $\begin{array}{l}\text { Prof. Dr. Nurcholis } \\
\text { Madjid. }\end{array}$ & $\begin{array}{l}\text { Indonesian } \\
\text { Scholars }\end{array}$ & $\begin{array}{l}\text { Islam is open, tolerant, civilized, and } \\
\text { according to the basis of the Indonesian } \\
\text { state Pancasila. }\end{array}$ \\
\hline
\end{tabular}

\section{Humanity and Nationality}

In Islam, nationalism cannot be on the contrary to humanity, it has to be an actual form and fill humanity. Because of that, nationality does not contain hostility with other nations, contains a sense of unity, and with one will towards a life of tranquillity and happiness. Because Islam understands that people tend to stay in groups, that will eventually be communities 
or nations. This is in accordance with the word of God in surah al Hujurat verse 13:O mankind! We created you from a single (pair) of a male and a female, and made you into nations and tribes, that ye may know each other (not that ye may despise (each other). Verily the most honoured of you in the sight of Allah is (he who is) the most righteous of you. And Allah has full knowledge and is well acquainted (with all things). (Usman, Shaharuddin \& Abidin, 2017)

Considering the verse above, it is clear that communities of nations, according to Islam, are a group of individuals that is unitary in culture, country, and religion. There is a harmonious reciprocal relationship between members relating with various importance, customs, lifestyles, regulations, institutions, technical, problem solving, and others concerning the phenomenon of the presence of community as widely interpreted. al-Syaibany stated that characteristics of the Islamic community are as follows: 1) exists based on the attachment of iman towards Allah, 2) religion is always put first, 3) the presence of judgment of morals and morality in life, and 4) science is an important matter. (Muthoifin, 2019)

On humans, in the book L'Humanisme de L'Islam, Marcel A. Boisard's thinking is similar to the view of SyafiiMaarif, which is that the way of thinking is Islam is centered on Allah and al-Qur'an, the value of human depends on his relationship with God. The Islamic view covers the entire human condition. Revelations in Islam consists of many details, which means that an explanation leaving out just a single detail will give a mixed meaning. On the other hand, if explained modestly, it will raise wrong ideas about the main concepts. (Benthall, 2005)

Thus it is clear that Islamic principles regarding humanitarian teachings (humanism) such as justice, honesty, humanitarian solidarity, and tolerance, create obligations for each member of the Islamic community and individuals. These principles give rise to a climate of respect and guarding reciprocity, which is a practice of civilization based on religion. (Kaptein, 2017)

Seeing the description above, it can be underlined that humans are independent. If we deny human freedom, this means that we say that God is unfair because he tortures or rewards humans on the basis that humans are not free to choose something, namely that he is irresponsible. God himself is absolute freedom, but human freedom, even though it is only relative, also remains independence, as weak light is also light. Because humans do not know the future life provided by God for him, his actions arise from decisions taken by his will and intelligence. So humans are free and responsible for their choices. (Tajab, Madjid \& Hidayati, 2019)

While Table 1 shows the ideas and thought of Indonesian Muslim leaders, Syafii Ma'arif, has distinctive Islamic models and implementation in Indonesia. The ideas and views are compiled in Table 2.

Table 2: A. Syafii Ma'arif's Idea about Islam in Indonesia

\begin{tabular}{|c|c|c|}
\hline No & Islamic model & Implementation in Indonesia \\
\hline 1 & Adherents of Islamic teachings that are open/inclusive & Democratization in all national issues. \\
\hline 2 & Islam that upholds the values of freedom & Fully support religious and cultural diversity \\
\hline 3 & $\begin{array}{l}\text { Prioritize the meeting point and equality among fellow } \\
\text { human children }\end{array}$ & $\begin{array}{l}\text { Recognizing pluralism and diversity as a form of } \\
\text { women's Emancipation power }\end{array}$ \\
\hline 4 & Islam with a thousand features and expressions & Tolerant of ethnic groups and religions \\
\hline 5 & Developing Islam & The majority of Indonesia $+-80 \%$ are Muslim \\
\hline 6 & Islam that upholds human values & Humanists and humanity \\
\hline 7 & Uphold the future of Islam and Indonesia & $\begin{array}{l}\text { slam that is not separated by national identity } \\
\text { (Local wisdom) }\end{array}$ \\
\hline 8 & Sincerity in religion & $\begin{array}{l}\text { Nusantara with the understanding and ideology of } \\
\text { Pancasila as the basis of a state }\end{array}$ \\
\hline 9 & Interact across religions and across cultures & Inclusivism and tolerant \\
\hline 10 & $\begin{array}{l}\text { A perfect human who upholds the core teachings of the } \\
\text { Qur'an, namely as the mercy of the universe. }\end{array}$ & Islam in the frame of Indonesianity and humanity \\
\hline
\end{tabular}

Finally, according to the author's analysis, Syafii Maarif's views if Islam, Indonesianness, and humanity already go hand in hand in the mind, soul, and action of Muslims in Indonesia, then Islam Indonesia will be able to provide a solution towards major issues faced by the country. A form of Islam that is dynamic and friendly, that delivers justice, safety, and protection to the entire population of the archipelago. A form of Islam that entirely stands by the poor people and rejects poverty so that it will be successfully driven away from the Unitary State of the Republic of Indonesia. (Fancy, 2007; Biyanto, 2009)

\section{CONCLUSIONS}

The thinking of Ahmad Syafii Maarif about progressive Islam and Islam in the frame of Indonesianness and humanity as it is no longer the time for Muslims, who are the majority in this archipelago, to question the trilogy correlation between Islam, Indonesianness, and humanity. The three conceptions must be in the same breath and rhythm so that Islam that is thriving in 
Indonesia is Islam that is progressive, hospitable, open and rahmatan lil 'alamin. A. Syafii Maarif emphasized that if Islam, Indonesianness, and humanity already go hand in hand in the mind, soul, and action of Muslims in Indonesia than Islam Indonesia will be able to provide a solution towards major issues faced by the country. A form of Islam that is dynamic and friendly, that delivers justice, safety, and protection to the entire population of the archipelago. A form of Islam that entirely stands by the poor people and rejects poverty so that it will be successfully driven away from the Unitary State of the Republic of Indonesia.

\section{REFERENCES}

1. Askuri, A., \& Kuipers, J. C. (2019). An orientation to be a good millennial Muslims: state and the politics of naming in islamizing Java. Indonesian Journal of Islam and Muslim Societies, 9(1), 31-55. https://doi.org/10.18326/ijims.v9i1.31-55

2. Asroni, A. (2011). Pemikiran Ahmad Syafii Maarif tentang Negara dan Syariat Islam di Indonesia. Millah, 10(2), 355-374. https://doi.org/10.20885/millah.vol10.iss2.art8

3. Benthall, J. (2005). L'humanitarisme islamique. Cultures \& Conflits, 60, 103-122. https://doi.org/10.4000/conflits.1928

4. Biyanto, B. (2009). Plurarism Discourse: The Views of Young Muhammadiyah Intellectuals. Journal of Indonesian Islam, 3(2), 314-340. https://doi.org/10.15642/JIIS.2009.3.2.314-340

5. Damanhuri, D. (2016). Islam, Keindonesiaan, Dan Kemanusiaan (Telaah Pemikiran Ahmad Syafii Maarif). AlBanjari: Jurnal Ilmiah Ilmu-Ilmu Keislaman, 14(1)., 76-84. https://doi.org/10.1017/CBO9781107415324.004

6. Dogan, R. (2018). Discussion over Theological and Political Foundations of Caliphate in Islam. Journal of Islamic Studies, 6(2), 1-8. https://doi.org/10.15640/jisc.v6n2a1

7. Fancy, N. (2007). Lenn E. Goodman, Islamic Humanism, Journal of Near Eastern Studies, 66(2), 151-153. https://doi.org/10.1086/519049

8. Gunawan, I. (2013). Metode penelitian kualitatif. Jakarta: Bumi Aksara.

9. Hartono, Y., Haryanto, S., \& Asrowi, A. (2018). Character education in the perspective of humanistic theory: A case study in Indonesia. Educare: International Journal for Educational Studies, 10(2), 95-108.

10. Kaptein, N. J. (2017). Two Unknown Letters from the Kartini Family to MJ de Goeje. Archipel. Études interdisciplinaires sur le monde insulindien, 93, 109-117. https://doi.org/10.4000/archipel.405

11. Maarif, A. S. (2018). Islam, Humanity, and Indonesian Identity : reflections on history. Leiden University Press (pp. 1-289). Retrieved from https://openaccess.leidenuniv.nl/handle/1887/66818

12. Matin, U. A. (2019). The Roots of Violence in Western Social Theories: In Search of Solution for Islam and Modernity. Insaniyat: Journal of Islam and Humanities, 3(2)., 139-150. https://doi.org/10.15408/insaniyat.v3i2.11145

13. Muhammad, B. A., Rijal, N. K., \& Yumitro, G. (2018). The Roles of International Conference of Islamic Scholar (ICIS) in Conflict Resolution of South Thailand. Journal of Law, Policy and Globalization, 76, 71-77.

14. Muthoifin. (2019). Shariah Hotel And Mission Religion In Surakarta Indonesia. Humanities \& Social Sciences Reviews, 7(4), 973-979. https://doi.org/10.18510/hssr.2019.74133

15. Muthoifin, M. \& Nuha. (2016). The Optimization of Local Autonomy Politic for Nation Progress and Synergetic on Islamic Perspective. The 4th University Research Coloquium 2016, 72-79. Retrieved from https://publikasiilmiah.ums.ac.id/xmlui/handle/11617/7679. https://doi.org/10.18510/hssr.2019.74111

16. Nashir, H., Jinan, M., \& Setiaji, B. (2019). Muhammadiyah: the Political Behavior of Modernist Muslim Elite in Indonesia. Humanities \& Social Sciences Reviews, 7(4), 837-844. DOI: 10.18510/hssr.2019.74111

17. Nurmila, N. (2013). Indonesian Muslims' Discourse of Husband-Wife Relationship. Al-Jami'ah: Journal of Islamic Studies, 51(1), 61-79. https://doi.org/10.14421/ajis.2013.511.61-79

18. Pager, D., \& Western, B. (2012). Identifying discrimination at work: The use of field experiments. Journal of Social Issues, 68(2), 221-237. https://doi.org/10.1111/j.1540-4560.2012.01746.x

19. Septiaji, A. (2018). Social discrimination in antology of poetry essay atas nama cinta written by Denny Ja (content analysis research). Jurnal Penelitian Humaniora, 19(1), 61-72.

20. Sholikin, A. (2013). Pemikiran Politik Negara dan Agama Ahmad Syafii Maarif. Jurnal Politik Muda, 2(1), 194203.

21. Suprapto. (2017). Sasak muslims and interreligious harmony: Ethnographic study of the perang topat festival in Lombok - Indonesia. Journal of Indonesian Islam, 11(1), 77-98. https://doi.org/10.15642/JIIS.2017.11.1.77-98

22. Tajab, M., Madjid, A., \& Hidayati, M. (2019). Psychology Of Patience In Al-Misbāh Exegesis. Humanities \& Social Sciences Reviews, 7(5), 1221-1230. https://doi.org/10.18510/hssr.2019.75161

23. Tyson, A. (2003). Realities Of Discrimination In Indonesia: The Case Of The Civil Service. Jurnal Administrasi Publik, 2(2)., 203-221.

24. Usman, A. H., Shaharuddin, S. A., \& Abidin, S. Z. (2017). Humanism In Islamic Education: Indonesian References. 
International Journal of Asia-Pacific Studies, 13(1), 95-113. https://doi.org/10.21315/ijaps2017.13.1.5

25. Williams, C. (2007). Research Methods. Journal of Business and Economic Research, 5(3), 65-72.

26. Zuhdi, S., Kuswardani, Prakosa, A. L., Kurnianingsih, M., Astuti, W., \& Rahman, R. A. (2019). Domestic Violence As A Consequence Of Nusyuz Under The Islamic Law And Legislation Of Indonesia. Humanities \& Social Sciences Reviews, 7(2), 340-348. https://doi.org/10.18510/hssr.2019.7240 